\title{
MEMPELAJARI PEMBUATAN NUGGET KACANG MERAH
}

\author{
Thoriqul Huda ${ }^{1)}$ Hapsari Titi Palupi ${ }^{2)}$ \\ ${ }^{1)}$ Mahasiswa Ilmu dan Teknologi Pangan Fakultas Pertanian Universitas Yudharta \\ ${ }^{2)}$ Staf Pengajar Prodi ITP Fakultas Pertanian Universitas Yudharta Pasuruan
}

\begin{abstract}
Abstrak
Nugget merupakan makanan yang murah sehat karena serta memiliki kandungan gizi yang baik, maka digunakan kacang merah merah (Phaseolus vulgaris. L) sebagai pengganti daging Tujuan dari penelitian ini adalah : untuk mengetahui pengaruh lama perendaman kacang merah (Phaseolus vulgaris. L) terhadap kualitas nugget kacang merah. Perlakuan lama perendaman kacang merah (Phaseolus vulgaris. L) berpengaruh nyata terhadap kadar air, kadar protein, dan kadar serat, tekstur dan warna, karakteristik organileptik yang meliputi kesukaan tehadap warna, aroma, tekstur dan rasa.nugget kacang merah. Perlakuan terbaik adalah lama perendaman selama 48 jam dengan karakteristik kimia fisik yaitu: kadar air 50.61\%; protein 5.73\%; kadar serat $0.96 \%$; tekstur (fisik) $28.3 \mathrm{~mm} / \mathrm{g}$ det ; warna/kecerahan $41.2 \%$; warna/intensitas merah $14.15 \%$; sedangkan karakteristik oraganoleptik yaitu : rasa 3.9 (suka); aroma 3.25 (suka); warna 4.25 (suka) ; tekstur 4.65 (sangat suka).
\end{abstract}

Kata Kunci : Nugget, kacang merah, lama perendaman kacang merah

\section{PENDAHULUAN}

Salah satu kebutuhan masyarakat saat ini adalah tersedianya bahan makanan yang praktis, yaitu yang bersifat ready to cook (siap untuk dimasak) dan ready to eat (siap untuk dimakan). Nugget adalah salah satu produk olahan daging yang terbuat dari daging giling yang dicetak dalam bentuk potongan empat persegi. Potongan ini kemudian dilapisi dengan tepung berbumbu (battered dab breaded). Produk nugget dapat dibuat dari daging sapi, ayam, ikan dan lain-lain, tetapi yang popular dimasyarakat adalah nugget ayam. Nugget yang berasal dari daging mempunyai harga yang cukup mahal dan kurang terjangkau. Namun untuk dapat menghasilkan nugget murah dan terjangkau serta memiliki kandungan gizi yang baik, dapat dilakukan dengan penggunaan kacang merah merah (Phaseolus vulgaris. L) sebagai pengganti daging yang digunakan dalam pembuatan nugget (Anggeraini, 2012).

Kacang merah memiliki kandungan gizi yang sangat baik, hal ini sangat menguntungkan bagi kesehatan tubuh manusia apalagi jika diolah secara baik dan benar. Kacang merah kering merupakan sumber protein nabati, karbohidrat kompleks, serat, vitamin $\mathrm{B}$, folasin, tiamin, kalsium, fosfor, dan zat besi. Namun kelemahan dari kacang-kacangan adalah tingginya kandungan senyawa nirgizi yang sebagian besar didominasi oleh asam fitat (Astawan, 2009) dan tingginya bau langu yang mengakibatkan produk akhir menjadi kurang diterima masyarakat (Yodatama, 2011). Asam fitat akan membentuk ikatan kompleks dengan zat besi atau mineral lain, seperti seng, magnesium, dan kalsium, menjadi bentuk yang tidak larut dan sulit diserap tubuh (Suhanda, 2007). Beberapa penelitian menunjukkan 
bahwa proses perendaman, perebusan, dan pengupasan kulit dapat mengurangi kandungan senyawa nirgizi yang ada dalam tanaman-tanaman leguminosae (Mohamed, R., E.A. Abou-Arab, A.Y. Gibriel, N.M.H. Rasmy dan F.M. Abu Salem, 2011). Tujuan penelitian adalah mengetahui pengaruh lama perendaman kacang merah (Phaseolus vulgaris L) terhadap kualitas nugget kacang merah yang dihasilkan.

\section{METODE}

Bahan-bahan yang digunakan dalam pembuatan nugget kacang merah (Phaseolus vulgaris L) adalah kacang merah (pasar purwosari), tepung terigu (merk segitga biru), tepung tapioka (rosebrand), telur, dan bumbu-bumbu (garam, bawang putih dan merica)

Alat-alat yang dipergunakan untuk pembuatan nugget kacang merah (Phaseolus vulgaris L) adalah: kompor gas, dandang, pisau stainlees steel, baskom, food processor, timbangan, dan nampan.

Percobaan dilakukan dengan menggunakan rancangan acak tunggal (RAT) dengan 5 variabel dan masing-masing perlakuan diulang sebanyak 3 kali, yaitu : A1= Tanpa Perendaman Kacang Merah, A2 = Perendaman Kacang Merah 12 jam, A3 = Perendaman Kacang Merah 24 jam, A4 = Perendaman Kacang Merah 36 jam, A5 = Perendaman Kacang Merah 48 jam

Variabel yang diuji meliputi kadar protein, kadar serat, kadar air, meliputi tekstur/kekenyalan dan warna, dan organileptik kesukaan warna, aroma, tekstur dan rasa. Karakteristik organoleptik diperoleh dari pengisian skor kesukaan oleh panelis minimal 20 orang. Skala nilai kesukaan mulai 1 (sangat tidak suka) sampai 5 (sangat suka).

Analisa data dilakukan secara ANOVA dengan selang kepercayaan $5 \%$ dan $1 \%$. Apabila ditemukan pengaruh terhadap salah satu variebel maka dilanjutkan dengan uji beda nyata terkecil (BNT). Uji variabel rasa, aroma, warna dan tekstur dianalisis ragam dengan metode Friedman.

Pengambilan keputusan dilakukan untuk menentukan perlakuan terbaik mempertimbangkan ke lima variable tersebut. Metode pengambilan keputusan yang dipergunakan adalah metode indeks efektifitas (deGarmo, 1989) termodifikasi oleh Susrini (2003).

\section{Pelaksanaan Penelitian}

Tahap proses pembuatan nugget kacang merah (Phaseolus vulgaris. L) adalah :

- perendaman kacang merah sesuai perlakuan.

- proses blansir

- dilanjutkan dengan proses penghancuran kacang merah sampai halus.

- proses pencampuran bahan menjadi satu yang meliputi kacang merah yang sudah dihaluskan, tepung terigu, tepung tapioka, telur dan bumbu. menggunakan food processor.

- pencetakan pada loyang.

- pengukukusan selama 30 menit.

- pendinginan dengan suhu ruang.

- pemotongan dan pelapisan nugget dilanjutkan penggorengan 


\section{HASIL DAN PEMBAHASAN}

Sifat kimia fisik dari nugget kacang merah dari berbagai perlakuan dapat dilihat pada Tabel 1 dibawah.

\section{Kadar Air}

Berdasarkan hasil analisa kadar air yang dilakukan pada nugget kacang merah (Phaseolus vulgaris. L) diperoleh rata-rata kadar air antara $46.56 \%$ sampai dengan 50.61\%. Berdasarkan analisis ragam perlakuan perendaman pada kacang merah (Phaseolus vulgaris. L) dalam pembuatan nugget mempunyai pengaruh yang nyata .

Pada Tabel 1 menunjukkan bahwa kadar air nugget semakin meningkat bila waktu perendaman pada kacang merah semakin panjang. Kadar air nugget tertinggi diperoleh pada perlakuan perendaman kacang merah 48 jam yaitu $50.61 \%$ dan kadar air terkecil pada perlakuan tanpa perendaman $\quad 46.56 \%$. Proses perendaman menyebabkan air masuk dalam jaringan kacang dan teksur menjadi lunak dan membengkak. Kondisi ini akan meningkatkan kadar air air nugget yang dihasilkan. Berdasarkan penelitian Agustina dkk (2013) menunjukkan bahwa perendaman kacang merah mengakibatkan dimensi kacang merah (panjang, tinggi, dan lebar) menjadi lebih besar dan akhirnya mencapai dimensi maksimum. Perubahan dimensi tersebut dikarenakan masuknya air ke dalam kacang merah melalui proses difusi. Kacang-kacangan mengandung banyak granula pati yang tersusun dari amilosa. Menurut Zamindar et. al. (2013) semakin lama waktu perendaman maka akan meningkatkan water absorption kacang merah. Kondisi ini tentu saja akan meningkatkan kadar air produk hasil olahan dari kacang merah.

Tabel 1. Komposisi kimia dan sifat fisik dari nugget kacang merah dengan berbagai perlakuan

\begin{tabular}{|l|c|c|c|c|c|}
\hline \multirow{2}{*}{ Komposisi } & \multicolumn{5}{|c|}{ Lama waktu perendaman (jam) } \\
\cline { 2 - 6 } & 0 jam & 12 jam & 24 jam & 36 jam & 48 jam \\
\hline Kadar air (\%) & 46.56 & 47,50 & 48.74 & 49.30 & 50.61 \\
\hline Kadar protein (\%) & 7.07 & 6.78 & 6.43 & 6.17 & 5.73 \\
\hline Kadar serat (\%) & 2.50 & 2.22 & 2.10 & 1.42 & 0.96 \\
\hline Warna (\%) (L/kecerahan) & 36.6 & 37.2 & 38.4 & 39.5 & 41.2 \\
\hline Warna (\%) (a/kemerahan) & 19.8 & 17.5 & 16.9 & 15.6 & 14.15 \\
\hline Tekstur mm/g det & 20.9 & 22.3 & 24.2 & 26.0 & 28.3 \\
\hline
\end{tabular}

\section{Kadar Protein}

Kadar protein yang dilakukan pada nugget kacang merah (Phaseolus vulgaris. L) diperoleh rata-rata kadar serat antara $5.73 \%$ sampai dengan $7.07 \%$. Hasil analisis ragam menunjukkan bahwa perlakuan perendaman pada kacang merah (Phaseolus vulgaris. L) dalam pembuatan nugget memberikan pengaruh sangat berbeda nyata pada kadar protein nugget.

Kadar protein nugget tertinggi diperoleh pada perlakuan tanpa perendaman $7.07 \%$ dan kadar protein nugget terkecil pada perlakuan perendaman kacang merah 48 jam yaitu $5.73 \%$. Kadar protein nugget menurun akibat waktu perendaman kacang merah yang semakin lama. Kacang merah mengandung protein 
yang bersifat larut dalam air akan terlarut dan terurai akibat proses perendaman. Semakin lama waktu perendaman kacang, maka jumlah protein yang bersifat larut air akan berkurang. Selain itu proses perendaman menyebabkan enzim proteolitik menjadi aktif sehingga akan memecah protein menjadi asam amino. Menurut Fernandes (2010) proses perendaman dapat menurunkan kadar protein tetapi daya cerna protein semakin meningkat

\section{Kadar Serat Kasar}

Berdasarkan hasil analisa kadar serat kasar yang dilakukan pada nugget kacang merah (Phaseolus vulgaris. L) diperoleh rata-rata kadar serat antara $0.96 \%$ sampai dengan $2.50 \%$. Kadar serat tertinggi diperoleh pada perlakuan tanpa perendaman yaitu $2.50 \%$ dan kadar serat terkecil diperoleh pada perlakuan perendaman kacang merah 48 jam yaitu $0.96 \%$. Semakin lama perendaman pada kacang merah maka nilai serat nugget kacang merah akan semakin menurun. Serat kasar adalah komponen bahan pangan yang tahan terhadap enzim amilase. Serat kasar terdiri dari dua golongan yaitu serat tidak larut dan serat larut. Serat larut pada kacang merah akibat proses perendaman akan terlarut dalam air, sehingga mempengaruhi jumlah kadar serat kasar nugget kacang merah.

\section{Tekstur}

Tekstur nugget kacang merah (Phaseolus vulgaris. L) diperoleh rata-rata antara $20.9 \mathrm{~mm} / \mathrm{g}$ det sampai dengan $28.3 \mathrm{~mm} / \mathrm{g}$ det. Hasil analisis ragam menunjukkan bahwa perlakuan perendaman pada kacang merah (Phaseolus vulgaris. L) dalam pembuatan nugget berpengaruh sangat berbeda nyata .
Pada Tabel 1 menunjukkan bahwa tekstur semakin meningkat bila perendaman pada kacang merah dilakukan semakin lama. Tekstur tertinggi diperoleh pada perlakuan perendaman kacang merah 48 jam yaitu $28.3 \mathrm{~mm} / \mathrm{g}$ det. Semakin lama perendaman pada kacang merah maka nilai tekstur nugget kacang merah juga akan semakin meningkat. Berdasarkan penelitian Zamindar et. al, 2013 proses perendaman pada kacang merah akan memperbaiki digestibility dan meningkatkan daya cerna pada produk hasil olahan kacang merah.

\section{Warna}

Pengukuran warna menggunakan Chromameter Minolla memberikam skala L* mengukur nilai kecerahan antara hitam sampai putih, koordinat nilai $\quad \mathrm{L}=0 \quad$ sampai $\quad \mathrm{L}=100$. Berdasarkan hasil analisa tingkat kecerahan (L*/lightness) yang dilakukan pada nugget kacang merah (Phaseolus vulgaris. L) diperoleh rata-rata tingkat kecerahan antara $36.6 \%$ sampai dengan $40.2 \%$. Berdasarkan analisis ragam perlakuan perendaman pada kacang merah (Phaseolus vulgaris. L) mempunyai pengaruh sangat berbeda nyata (BNT $5 \%$ ) terhadap nugget kacang merah yang dihasilkan.

Tabel 1 menunjukkan bahwa nilai kecerahan semakin meningkat bila perendaman pada kacang merah dilakukan semakin lama. Nilai kecerahan tertinggi diperoleh pada perlakuan perendaman pada kacang merah 48 jam yaitu $40.2 \%$ dan nilai kecerahan terkecil diperoleh pada perlakuan tanpa perendaman yaitu $36.6 \%$. Semakin lama perendaman pada kacang merah maka nilai rata-rata kecerahan nugget kacang merah akan semakin meningkat. 
Perendaman kacang merah (Phaseolus vulgaris. L) juga berpengaruh nyata terhadap nilai a (redness). Nilai a menunjukkan warna hijau (a negatif) sampai merah (a positif). Hasil penelitian menunjukkan bahwa kacang merah (Phaseolus vulgaris. L) memberikan nilai a pada kisaran warna merah. Berdasarkan hasil analisa tingkat kemerahan (a*/redness) yang dilakukan pada nugget kacang merah (Phaseolus vulgaris. L) diperoleh rata-rata tingkat kemerahan antara $14.15 \%$ sampai dengan $19.8 \%$. Rata-rata nilai kemerahan $\left(\mathrm{a}^{*} /\right.$ redness $)$ pada setiap perlakuan dapat dilihat pada Tabel 1 .
Tabel 1 menunjukkan bahwa rata-rata tingkat kemerahan semakin menurun bila perendaman pada kacang merah dilakukan semakin lama. Nilai tingkat kemerahan tertinggi diperoleh pada perlakuan A1 (tanpa perendaman) sebesar $19.8 \%$ nilai tingkat kemerahan terkecil diperoleh pada perlakuan A5 (perendaman pada kacang merah selama 48 jam) sebesar 14.15\%. Semakin lama perendaman pada kacang merah maka nilai tingkat kemerahan nugget kacang merah akan semakin menurun. Penurunan disebabkan oleh degradasi selama proses perendaman

\section{Organoleptik}

Tabel 2 Nilai Kesukaan Terhadap Organoleptik Nugget Kacang Tanah

\begin{tabular}{|l|c|c|c|c|c|}
\hline \multirow{2}{*}{ Organoleptik } & \multicolumn{5}{|c|}{ Lama waktu perendaman (jam) } \\
\cline { 2 - 6 } & 0 jam & 12 jam & 24 jam & 36 jam & 48 jam \\
\hline Warna & 2.85 & 3.30 & 3.70 & 4.05 & 4.25 \\
\hline Rasa & 3.00 & 3.30 & 3.45 & 3.75 & 3.90 \\
\hline Aroma & 2.50 & 3.30 & 3.40 & 3.30 & 3.25 \\
\hline Tekstur & 2.50 & 3.30 & 3.80 & 4.30 & 4.65 \\
\hline
\end{tabular}

Berdasarkan pengamatan organoleptik oleh 20 panelis terhadap nugget kacang merah, nilai kesukaan terhadap organoleptik warna, rasa, tekstur dapat dilihat pada Tabel 2.

\section{Warna}

Berdasarkan analisis ragam perlakuan perendaman pada kacang merah (Phaseolus vulgaris. L) mempunyai pengaruh sangat berbeda nyata terhadap warna nugget kacang merah yang dihasilkan. Nilai kesukaan terhadap tekstur adalah 2.85 (netral) sampai 4.25 ( suka). Semakin lama perendaman pada kacang merah maka tingkat kesukaan pada warna nugget semakin meningkat.

\section{Rasa}

Berdasarkan analisis ragam perlakuan perendaman pada kacang merah (Phaseolus vulgaris. L) mempunyai pengaruh sangat berbeda nyata (BNT 5\%) terhadap nugget kacang merah yang dihasilkan. Dari hasil uji organoleptik nilai kesukaan rasa nugget adalah 3,00 (netral) sampai 3.90 (suka) .Nilai kesukaan tertinggi pada perlakuan perendaman kacang merah 48 jam dan kesukaan terendah pada perlakuan perendaman kacang merah 0 jam. Semakain lama waktu perendaman kacang merah tingkat kesukaaan panelis pada nugget kacang merah semakin meningkat. 


\section{Tekstur}

Berdasarkan analisis ragam perlakuan perendaman pada kacang merah (Phaseolus vulgaris. L) mempunyai pengaruh sangat berbeda nyata (BNT 5\%) terhadap nugget kacang merah yang dihasilkan. Nilai kesukaan terhadap tekstur adalah 2.50 (tidak suka) sampai 4.65 (sangat suka). Semakin lama perendaman pada kacang merah maka tingkat kesukaan pada tekstur nugget semakin meningkat. Hal ini didukung oleh analisa fisik tekstur pada nugget menunjukkan bahwa tekstur semakin meningkat bila perendaman pada kacang merah dilakukan semakin lama. Proses perendaman pada kacang merah akan menyebabkan peruraian komponen kompleks menjadi komponen sederhana akibat akibat masuknya air kedalam bagaian biji kacang merah dan aktifitas enzim. meningkatkan daya cerna pada produk hasil olahan kacang merah, sehingga tekstur nugget lebih lunak dan kondisi ini disukai panelis.

\section{Aroma}

Berdasarkan analisis ragam perlakuan perendaman pada kacang merah (Phaseolus vulgaris. L) mempunyai pengaruh sangat berbeda nyata terhadap nugget kacang merah

\section{KESIMPULAN}

1. Perlakuan lama perendaman kacang merah (Phaseolus vulgaris. L) berpengaruh nyata terhadap kadar air, kadar protein, kadar serat, tekstur, warna, serta organileptik warna, aroma, tekstur dan rasa nugget kacang merah.

2.Perlakuan yang menghasilkan nugget terbaik adalah perlakuan lama perendaman kacang merah selama 48 jam dengan dengan yang dihasilkan Nilai kesukaan aroma nugget adalah 2.50 (tidak suka) sampai 3.40 (netral).

Nilai kesukaan tertinggi pada perlakuan perendaman kacang merah 48 jam dan kesukaan terendah pada perlakuan perendaman kacang merah 0 jam yaitu dengan skor 2.50 (tidak suka). Proses perendaman biji kacang merah pada suhu ruang dengan waktu yang lama dapat berpengaruh terhadap kualitas produk, warna, rasa, dan bau Agustina dkk (2013)

\section{Pemilihan Alternative Terbaik Penelitian Dengan Indeks Efektifitas}

Hasil perhitungan menggunakan metode indeks infektifitas, diperoleh perlakuan terbaik terdapat pada perlakuan lama perendaman selama 48 jam dengan dengan menghasilkan sifat kimia fisik dan organoleptik yaitu kadar air 50.61\%; protein 5.73\%; kadar serat $0.96 \%$; tekstur (fisik) 28.3 $\mathrm{mm} / \mathrm{g}$ det; warna/kecerahan $41.2 \%$; warna/intensitas merah $14.15 \%$; organoleptik rasa 3.9 (suka); organoleptik aroma 3.25 (suka); organoleptik warna 4.25 (suka); dan organoleptik tekstur 4.65 (sangat suka).

menghasilkan sifat kimia fisik dan organoleptik yaitu kadar air 50.61\%; protein $5.73 \%$; kadar serat $0.96 \%$; tekstur (fisik) $28.3 \mathrm{~mm} / \mathrm{g}$ det; warna/kecerahan $\quad 41.2 \%$; warna/intensitas merah $14.15 \%$; organoleptik rasa 3.9 (suka); organoleptik aroma 3.25 (suka); organoleptik warna 4.25 (suka); dan organoleptik tekstur 4.65 (sangat suka). 


\section{DAFTAR PUSTAKA}

Aisha M. Nakitto, John H. Muyonga and Dorothy Nakimbugwe* 2015 Effects of combined traditional processing methods on the nutritional quality of beans. Food Science \& Nutrition. Volume 3, Issue 3, pages 233-241, May 2015

Anggeraini, A. 2012. Pengaruh Jumlah Wortel dan Lama Pengukusan Terhadap Mutu Nugget. Skripsi. Program Studi Ilmu dan Teknologi Pangan. Fakultas Pertanian. Medan : Universitas Sumatera Utara.

Agustina, Nanik., Sri Waluyo, Warji, Tamrin. 2013. Pengaruh Suhu Perendaman Terhadap Koefisien Difusi dan Sifat Fisik Kacang Merah (Phaseolus vulgaris L.). Jurnal Teknik Pertanian Lampung-Vol. 2, No. 1: 35 - 42

Astawan, M. 2009. Sehat dengan Hidangan Kacang \& Biji-Bijian. Penerbit Swadaya. Depok.

Fernandes, Ana C., Waleska Nishida \& Rossana P. da Costa Proenc. 2010. Influence of soaking on the nutritional quality of common beans (Phaseolus vulgaris L.) cooked with or without the soaking water: International Journal of Food Science and Technology 2010, 45, 2209-2218

Mohamed, R., E.A. Abou-Arab, A.Y. Gibriel, N.M.H. Rasmy, dan F.M. Abu Salem. 2011. Effect of Legume Processing Treatments Individually or In Combination on Their Phytic Acid Content. African Journal of Food Science and Technology.

Nafiseh Zamindar, Mohamad Shahedi Baghekhandan, Ali Nasirpour, and Mahmoud Sheikhzeinoddin. Effects of combined traditional processing methods on the nutritional quality of beans. J Food Sci Technol. 2013 Feb; 50(1): 108-114. Published online 2011 Jan 21. doi: 10.1007/s13197-011-0234-2

Suhanda, I. 2007. Sehat dengan Makanan Berkhasiat. Penerbit Buku Kompas. Jakarta.

Yodatama, K.K. 2011. Perencanaan Unit Pengolahan "Brownies" Kacang Merah (Phaseolus vulgaris L.) Skala Industri Kecil. Skripsi Fakultas Teknologi Pertanian, Universitas Brawijaya. Malang. 